\title{
Produção, purificação e caracterização de um peptídeo antimicrobiano produzido por uma linhagem de Bacillus sp. P34*
}

\author{
AMANDA DE SOUZA DA MOTTA
}

\author{
Adriano Brandelli (Orientador - UFRGS) \\ Banca: Marisa Ribeiro de Itapema Cardoso (UFRGS), Plinho Francisco Hertz (UFRGS), Leadir Lucy Martins Fries (UFSM)
}

Uma bactéria identificada como Bacillus sp. P34 isolada de intestino de peixe (Leporinus sp.) da Bacia Amazônica foi estudada quanto a sua capacidade de produzir substâncias do tipo-bacteriocina. As condições ótimas para produção da substância antimicrobiana foram determinadas. A produção da atividade antimicrobiana foi observada começando na fase exponencial de crescimento, sendo a atividade máxima observada no início da fase estacionária. Os resultados da Análise de Superfície de Resposta mostraram que a máxima produção da atividade antimicrobiana ocorreu a pH inicial entre 6.0 e 8.0 e temperaturas entre 25 e $37^{\circ} \mathrm{C}$. A substância inibiu bactérias patogênicas e deteriorantes importantes em alimentos como Listeria monocytogenes, Bacillus cereus, Aeromonas hydrophila, Erwinia carotovora e Pasteurella haemolytica. O teste de termoestabilidade mostrou a perda de atividade quando a temperatura alcançou $100^{\circ} \mathrm{C}$ por 15 minutos. Foi sensível à ação das enzimas proteolíticas tripsina, papaína e pronase E. A substância antimicrobiana apresentou efeito bactericida e bacteriolítico sobre L. monocytogenes e B. cereus a $160 \mathrm{UA} \mathrm{ml}^{-1}$. O crescimento de Escherichia coli and Salmonella Enteritidis foi inibido somente quando o agente quelante EDTA foi adicionado juntamente. A atividade esporocida não foi observada. A análise da cultura de L. monocytogenes depois do tratamento com o composto antimicrobiano, usando espectroscopia de infravermelho com transformada de Fourier mostrou alterações no perfil de ácidos graxos e fosfolipídios da membrana celular bacteriana. Há evidências de que seu modo de ação interfira na membrana e na parede celular. A substância foi purificada pelo seguinte protocolo: precipitação com sulfato de amônio, cromatografias de gel filtração e de troca iônica. O peso molecular da substância foi determinado por espectroscopia de massas sendo 1498.68 Da. A substância antimicrobiana purificada apresentou sensibilidade ao tratamento com proteases e manutenção da atividade foi observada após congelamento e à incubação de $70^{\circ} \mathrm{C}$ por 30 minutos.

Descritores: atividade antimicrobiana, bacteriocina, Bacillus sp., Listeria monocytogenes.

Apresentada: 22 fevereiro 2006

*Tese de Doutorado n. 65 (Especialidade: Bacteriologia). 163f. Programa de Pós-graduação em Ciências Veterinárias [www.ufrgs.br/ppgcv], Faculdade de Veterinária, Universidade Federal do Rio Grande do Sul (UFRGS), Porto Alegre/RS. CORRESPONDÊNCIA: A.S. Motta [asmcons@ig.com.br; asmcons@gmail.com]. 


\title{
Production, purification and characterization of the antibacterial peptide produced by a strain of Bacillus sp. P34*
}

\author{
AMANDA DE SOUZA DA MOTTA
}

Adriano Brandelli (Adviser - UFRGS)

Committee: Marisa Ribeiro Itapema Cardoso (UFRGS), Plinho Francisco Hertz (UFRGS), Leadir Lucy Martins Fries (UFSM)

\begin{abstract}
A bacterium identified as Bacillus sp. strain P34 isolated from fish intestine (Leporinus sp.) from the Amazon basin was studied in its capacity to produce bacteriocin-like substances. The optimal conditions for producing the antimicrobial activity have been established. The antimicrobial activity was produced starting at the exponencial growth phase, and maximum activity was observed at early stationary phase. Response-surface data showed that maximum antimicrobial activity production was at initial $\mathrm{pH}$ between 6.0 and 8.0 and temperature between 25 and $37^{\circ} \mathrm{C}$. The antimicrobial substance inhibited pathogenic and spoilage food bacteria such as Listeria monocytogenes, Bacillus cereus, Aeromonas hydrophila, Erwinia carotovora and Pasteurella haemolytica. The thermoestability test showed the loss of activity when the temperature reached $100^{\circ} \mathrm{C}$ for 15 min. It was sensitive to the proteolytic action of trypsin, papain and pronase $\mathrm{E}$. The antimicrobial substance was bactericidal and bacteriolytic to L. monocytogenes and B. cereus at $160 \mathrm{AU} \mathrm{ml}^{-1}$. Growth of Escherichia coli and Salmonella Enteritidis was inhibited, but only when the chelating agent EDTA was co-added. Sporocidal activity was not observed. The analysis of the culture of $L$. monocytogenes after being treated with antimicrobial compound, using Fourier transform infrared spectroscopy, established a change in the profile that corresponding assignments of fatty acid and phospholipids. There was evidence that its mode of action to interfere with cell membrane and the cell wall. The substance was purified by the following protocol: precipitation with ammonium sulphate, gel filtration and ion exchange chromatography. The molecular weight was determined by mass spectroscopy as $1498.68 \mathrm{Da}$. Purified antimicrobial substance has shown sensitivity to protease treatment and maintained activity after freezing and incubation at $70^{\circ} \mathrm{C}$ for $30 \mathrm{~min}$.
\end{abstract}

Key words: antimicrobial activity, bacteriocin, Bacillus sp., Listeria monocytogenes. 